\title{
Protein-energy malnutrition halts hemopoietic progenitor cells in the G0/G1 cell cycle stage, thereby altering cell production rates
}

\author{
P. Borelli ${ }^{1}$, F.E.V. Barros ${ }^{1}$, K. Nakajima ${ }^{1}$, S.L. Blatt ${ }^{1}$, B. Beutler ${ }^{2}$, J. Pereira ${ }^{2}$, M. Tsujita ${ }^{2}$, \\ G.M. Favero ${ }^{2}$ and R.A. Fock ${ }^{1}$ \\ ${ }^{1}$ Laboratório de Hematologia Experimental, Departamento de Análises Clínicas e Toxicológicas, \\ Faculdade de Ciências Farmacêuticas, Universidade de São Paulo, São Paulo, SP, Brasil \\ ${ }^{2}$ Fundação Pró-Sangue Hemocentro de São Paulo, Laboratório de Imunopatologia, Hospital das Clínicas, \\ Faculdade de Medicina, Universidade de São Paulo, São Paulo, SP, Brasil \\ Correspondence to: P. Borelli, Departamento de Análises Clínicas e Toxicológicas, Faculdade de \\ Ciências Farmacêuticas, USP, Av. Prof. Lineu Prestes, 580, Bloco 17, 05508-900 São Paulo, SP, Brasil \\ Fax: +55-11-3813-2197. E-mail: borelli@usp.br
}

Protein energy malnutrition (PEM) is a syndrome that often results in immunodeficiency coupled with pancytopenia. Hemopoietic tissue requires a high nutrient supply and the proliferation, differentiation and maturation of cells occur in a constant and balanced manner, sensitive to the demands of specific cell lineages and dependent on the stem cell population. In the present study, we evaluated the effect of PEM on some aspects of hemopoiesis, analyzing the cell cycle of bone marrow cells and the percentage of progenitor cells in the bone marrow. Two-month-old male Swiss mice ( $N=7-9$ per group) were submitted to PEM with a low-protein diet (4\%) or were fed a control diet (20\% protein) ad libitum. When the experimental group had lost about $20 \%$ of their original body weight after 14 days, we collected blood and bone marrow cells to determine the percentage of progenitor cells and the number of cells in each phase of the cell cycle. Animals of both groups were stimulated with 5-fluorouracil. Blood analysis, bone marrow cell composition and cell cycle evaluation was performed after 10 days. Malnourished animals presented anemia, reticulocytopenia and leukopenia. Their bone marrow was hypocellular and depleted of progenitor cells. Malnourished animals also presented more cells than normal in phases G0 and G1 of the cell cycle. Thus, we conclude that PEM leads to the depletion of progenitor hemopoietic populations and changes in cellular development. We suggest that these changes are some of the primary causes of pancytopenia in cases of PEM.

Key words: Malnutrition; Hemopoiesis; Cell cycle; Low protein diet

Research supported by FAPESP and CNPq.

Received September 12, 2008. Accepted March 3, 2009

\section{Introduction}

The four most important deficiency diseases in developing countries are protein-energy malnutrition (PEM), xerophthalmia, nutritional anemias, and iodine deficiency disorders (1). Of these, PEM is the most important and also the most difficult to control. The immediate cause is usually insufficient intake or improper utilization of energy and protein $(2,3)$.

PEM is one of the main causes of immunodepression (4), modifying both the adaptive and innate immune system, as well as impairing hemopoiesis by altering T-dependent areas of the lymphoid tissue (5), decreasing phagocytosis (6), hindering respiratory burst, reducing nitric oxide availability (7), down-regulating proinflammatory cytokine production (8). 
The literature describes an alternation between leukopenia and leukocytes, especially in humans. This is consistent with the fact that malnutrition is usually associated with infection or chronic disease $(9,10)$. However, conflicting literature reports may be explained by the different kinds of nutritional deficiencies and other associated pathological processes. Even though the leukocyte response is variable, there is evidence that in situations where malnutrition is not associated with other diseases, leukopenia will tend to dominate $(8,10,11)$.

Hemopoietic tissue, like all tissues that have a high rate of cell renewal and proliferation, requires a large supply of nutrients. The anemia, leukopenia and bone marrow hypoplasia that occur in a state of PEM seem to be the product of inefficient hemopoiesis, and inefficient myelopoiesis in particular $(5,12)$. It has been reported that the proliferative capacity of bone marrow and the spleen is hindered in malnourished mice and that there is a reduction in the number of pluripotent cells and an increase in the time taken for a single cell cycle to be completed (13). Malnutrition reduces the number of granulo-monocytic colony forming units (14) and leads to DNA damage (15) and to cytogenetic alterations (16). The exact mechanisms underlying these findings are not clear. Thus, the objective of the present study was to evaluate the proliferative capacity of hemopoietic progenitor cells in mice during PEM.

\section{Material and Methods}

\section{Diets}

The murine diets were prepared in our laboratories. Mineral and vitamin mixtures were prepared according to the recommendations of the American Institute of Nutrition for adult mice (17). Both diets contained $100 \mathrm{~g} / \mathrm{kg}$ sucrose, $80 \mathrm{~g} / \mathrm{kg}$ corn oil, $10 \mathrm{~g} / \mathrm{kg}$ fiber, $2.5 \mathrm{~g} / \mathrm{kg}$ choline bitartrate, $1.5 \mathrm{~g} / \mathrm{kg}$ L-methionine, $40 \mathrm{~g} / \mathrm{kg}$ mineral mixture, and $10 \mathrm{~g} /$ $\mathrm{kg}$ vitamin mixture. The control diet contained $200 \mathrm{~g} / \mathrm{kg}$ casein and $556 \mathrm{~g} / \mathrm{kg}$ cornstarch while the malnourished diet contained $40 \mathrm{~g} / \mathrm{kg}$ casein and $716 \mathrm{~g} / \mathrm{kg}$ cornstarch. Casein (>85\% protein) was the protein source. Both diets were isocaloric and provided $1716.3 \mathrm{~kJ} / 100 \mathrm{~g}$. Final protein content was confirmed using the standard microKjeldahl method (18).

\section{Animals}

Male outbred Swiss mice 2 to 3 months of age were obtained from the Faculty of Pharmaceutical Sciences, University of São Paulo. The animals were placed in individual "metabolic cages" and received the control diet for 21 days. After this period of adaptation, the mice reached a stable body weight. They were subsequently divided into four groups, i.e., control (C), control + 5fluorouracil $(\mathrm{C}+5 \mathrm{~F})$, malnourished $(\mathrm{M})$, and malnourished + 5-fluorouracil $(M+5 F)$. Each group was maintained under a regular 12/12-h light/dark cycle at a temperature of $22-25^{\circ} \mathrm{C}$ and humidity of $55 \%$. The groups received either the control diet or the low-protein diet ad libtum and had free access to water. Their body weight and food consumption were monitored every $48 \mathrm{~h}$. Mice were subjected to experimental assays after 14 days of eating their respective diets, by which time the malnourished group lost about $20 \%$ of their original body weight (6). For the collection of the different biological samples, the animals were first anesthetized with $10 \mathrm{mg} / \mathrm{kg}$ xylazine chlorohydrate (Rompum ${ }^{\circledR}$, Bayer, Brazil) and with $100 \mathrm{mg} / \mathrm{kg}$ ketamide chlorohydrate (Ketamina ${ }^{\circledR}$, Cristália, Brazil). The study was approved by the Ethics Commission for Animal Studies of the Faculty of Pharmaceutical Sciences, University of São Paulo.

\section{5-Fluorouracil administration}

Animals from control and malnourished groups $(\mathrm{C}+5 \mathrm{~F}$ and $\mathrm{M}+5 \mathrm{~F}$ ) received $150 \mathrm{mg} / \mathrm{kg}$ 5-fluorouracil (American Pharmaceutical Patterns, USA) intravenously via the caudal vein, and after 10 days, control $(C+5 F)$ and malnourished $(\mathrm{M}+5 \mathrm{~F})$ animals were anesthetized to permit collection of various biological samples.

\section{Blood}

The mice were anesthetized and whole blood samples were obtained by cardiac puncture. The blood samples were collected into tubes containing EDTA as anticoagulant (Sigma, USA). Hemoglobin concentration and hematocrit were determined by standard methods (19). Total cell counts were obtained using a Neubauer chamber (Herka, Germany). Differential leukocyte counts were performed on blood smears stained with standard MayGrunwald and Giemsa solutions (Sigma). Plasma was separated by centrifugation and the albumin and total protein concentrations were determined by standard methods used in medical analysis $(20,21)$.

\section{Bone marrow cellularity}

Femurs were removed under aseptic conditions, and bone marrow cells were flushed from them using Fisher medium (Sigma) supplemented with $10 \%$ fetal calf serum (Cultilab, Brazil) and $50 \mathrm{U} / \mathrm{mL}$ heparin (Liquemine ${ }^{\circledR}$, Roche, Brazil). The resulting preparations were then used for the myelogram and for flow cytometry. Total cell counts were first carried out, followed by differential counts using a cytocentrifuge. The smears were stained with standard May-Grunwald and Giemsa solutions (Sigma). Differential 
cell counts were performed on the basis of counts of 300 cells per slide/animal.

Bone marrow progenitor quantification: $\mathrm{CD} 45^{+} / \mathrm{CD} 4^{+}$ and $\mathrm{CD} 117^{+} / \mathrm{CD}^{+} 4^{+}$

Flow cytometry was used to determine the fraction of bone marrow cells from control and malnourished animals that could be positively labeled with antibodies (phycoerythrin (PE) and fluorescein isothiocyanate (FITC); Becton Dickinson Pharmigen, USA) against CD45 (FITC, LY-5, clone 30-F11), CD34 (PE, clone RAM 34), and CD117 (FITC, clone 2B8). The isotype controls were rat immunoglobulins IgG 2a kappa, FITC (clone R35-95) for CD34 and IgG 2b kappa FITC (clone A95-1) for CD45 and CD117. For the immunophenotyping experiments, total cell suspensions were first obtained from bone marrow. The samples and negative controls were incubated with $1 \mu \mathrm{g}$ monoclonal antibody $/ 10^{6}$ cells $/ \mathrm{mL}$ for $20 \mathrm{~min}$ in the dark at $25^{\circ} \mathrm{C}$. After this period, the erythrocytes were lysed by adding $2 \mathrm{~mL} 10 \%$ lysing solution (Lysing Solution ${ }^{\circledR}$, Becton Dickinson) and were incubated again for $15 \mathrm{~min}$ in the dark. Next, the tubes were centrifuged at $400 \mathrm{~g}$ for $10 \mathrm{~min}$, the supernatant was discarded and the cell sediment was washed twice with phosphate-buffered saline (PBS; Sigma) containing $0.1 \%$ azide. The sediment was re-suspended in $500 \mu \mathrm{L} 1 \%$ paraformaldehyde (Sigma) and cells were counted with a flow cytometer. Dual parameter flow cytometry was carried out with a fluorescence-activated cell sorter (FACS)Calibur instrument (Becton Dickinson) equipped with an argon laser. Excitation occurred at 488 $\mathrm{nm}$ for both FITC and PE. Fluorescence measurements were obtained with a minimum of $1 \times 10^{4}$ cells. Data were analyzed using the Cell Quest ${ }^{\circledR}$ software package and the results are reported as percentage of gated populations.

\section{Cell cycle assessments: propidium iodide and acridine} orange

We evaluated the cell cycle phases of bone marrow cells from both control and malnourished groups with or without 5-fluorouracil using propidium iodide and acridine orange staining.

\section{Propidium iodide}

Bone marrow cells collected from all groups were adjusted to a final concentration of $1 \times 10^{6}$ cells $/ \mathrm{mL}$ in PBS. Nine milliliters $100 \%$ ethanol (Sigma) was added to $1 \mathrm{~mL}$ of a cell suspension that was subsequently maintained at $4^{\circ} \mathrm{C}$ for $4 \mathrm{~h}$. The samples were then centrifuged for $5 \mathrm{~min}$ at $300 \mathrm{~g}$, at $20-25^{\circ} \mathrm{C}$. After centrifugation, the pellet was resuspended in $200 \mu \mathrm{L}$ propidium iodide solution of the following composition: $50 \mu \mathrm{L}$ propidium iodide (Becton
Dickinson Pharmigen), $400 \mu \mathrm{L}$ Triton X-100 (Sigma), 200 $\mu \mathrm{L}$ ribonuclease (Sigma), and $4350 \mu \mathrm{L}$ PBS. The analyses were performed by flow cytometry using the FACSCalibur instrument (Becton Dickinson) equipped with an argon laser. Excitation occurred at $488 \mathrm{~nm}$. Data were analyzed using the Cell Quest ${ }^{\circledR}$ software package.

\section{Acridine orange}

A $100-\mu \mathrm{L}$ bone marrow cell suspension was prepared from each group. Each suspension contained $2 \times 10^{6}$ cells/ $\mathrm{mL}$. To this we added $400 \mu \mathrm{L}$ acid solution detergent $(0.1 \%$ Triton X-100, $0.08 \mathrm{~N} \mathrm{HCl}, 1.5 \mathrm{M} \mathrm{NaCl}$ ). After 15 s $600 \mu \mathrm{L} 20$ $\mu \mathrm{m}$ acridine orange (Sigma), $\mathrm{pH}$ 6.0, was added. Cell fluorescence was determined with the FACSCalibur instrument (Becton Dickinson) equipped with an argon laser. Excitation occurred at $488 \mathrm{~nm}$ and detection was performed with green $530 \pm 20 \mathrm{~nm}$ and red $620 \mathrm{~nm}$ illumination. Under these conditions, the intensity of green fluorescence is proportional to the DNA content, while the intensity of red fluorescence corresponds to the RNA content (22). Data were analyzed using the Cell Quest ${ }^{\circledR}$ software.

\section{Statistical analysis}

The dependent variables were normally distributed. Data are reported as means \pm SEM (one-way analysis of variance, ANOVA) and were compared by the Tukey multiple comparison test, with the level of significance set at $P$ $\leq 0.05$.

\section{Results}

Food and protein consumption, body weight variation, albumin and total plasma protein concentrations

Mice treated or not with 5-fluorouracil and maintained on the low-protein diet had reduced food and protein consumption, resulting in weight loss, as well as a significant reduction of protein consumption and, consequently, decreased albumin and total plasma protein concentrations (Table 1).

\section{Blood and bone marrow cellularity}

The undernourished animals treated or not with 5fluorouracil presented anemia with reticulopenia. They also exhibited leukopenia with granulocytic and lymphocytic depletion compared to their respective control groups (Table 2).

Differential counts of bone marrow cells from malnourished animals treated or not with 5-fluorouracil (Table 2) indicated a significant reduction in granulocytic cells, macrophages and erythroblasts. Malnourished mice of both groups exhibited a significant reduction in cell counts from 
all the maturation stages of the granulocytic lineage, consistent with a significant reduction in the erythrocytic component of the blood. Taken together, these results suggest a state of marrow failure, possibly due to the reduction of progenitor bone marrow cells.

Flow cytometry results: progenitor populations

The immunophenotypic analysis demonstrated the presence of three distinct cell populations; gate R1 was chosen to analyze progenitor antigen expression. Bone marrow cells from malnourished mice not treated with 5fluorouracil had a reduced number of cells expressing low intensity fluorescence (CD45) when compared with the control group that did not receive 5-fluorouracil. This indicates a reduction in the number of progenitor cells, as confirmed by the smaller number of cells, which expressed $\mathrm{CD}^{+} 5^{+} / \mathrm{CD} 34^{+}$and $\mathrm{CD} 117^{+} / \mathrm{CD} 34^{+}$(Figure 1 ). In malnourished animals that received 5 -fluorouracil, the results were

Table 1. Daily food and protein consumption, body weight variation, albumin concentration, and total plasma protein of control and malnourished animals treated or not with 5-fluorouracil.

\begin{tabular}{|c|c|c|c|c|}
\hline \multirow[t]{2}{*}{ Parameters } & \multicolumn{2}{|c|}{ Control } & \multicolumn{2}{|c|}{ Malnourished } \\
\hline & $\begin{array}{l}\text { Without 5-fluorouracil } \\
\qquad(\mathrm{N}=9)\end{array}$ & $\begin{array}{c}10 \text { days after } \\
5 \text {-fluorouracil }(\mathrm{N}=7)\end{array}$ & $\begin{array}{l}\text { Without 5-fluorouracil } \\
\qquad(\mathrm{N}=9)\end{array}$ & $\begin{array}{c}10 \text { days after } \\
\text { 5-fluorouracil }(\mathrm{N}=7)\end{array}$ \\
\hline Food consumption $\left(\mathrm{g} \cdot\right.$ day $^{-1} \cdot$ animal $\left.^{-1}\right)$ & $5.9 \pm 0.28$ & $5.6 \pm 0.31$ & $4.4 \pm 0.18^{a, b}$ & $4.1 \pm 0.27^{a, b}$ \\
\hline Protein consumption $\left(\mathrm{g} \cdot\right.$ day $^{-1} \cdot$ animal $\left.^{-1}\right)$ & $1.18 \pm 0.18$ & $1.12 \pm 0.12$ & $0.18 \pm 0.04^{a, b}$ & $0.17 \pm 0.09 a, b$ \\
\hline Body weight variation (\%) & $4.19 \pm 0.8$ & $4.1 \pm 0.6$ & $-22.2 \pm 1.4^{a, b}$ & $-23.7 \pm 1.9^{a, b}$ \\
\hline Albumin concentration (g/dL) & $4.2 \pm 0.6$ & $4.7 \pm 0.6$ & $3.1 \pm 0.4^{\mathrm{a}, \mathrm{b}}$ & $3.0 \pm 0.6^{\mathrm{a}, \mathrm{b}}$ \\
\hline Total plasma protein (g/dL) & $7.20 \pm 0.98$ & $6.8 \pm 1.1$ & $4.80 \pm 0.81^{a, b}$ & $4.30 \pm 0.88^{a, b}$ \\
\hline
\end{tabular}

Data are reported as means \pm SEM. aP $\leq 0.05$ control group without 5 -fluorouracil compared to the other groups; ${ }^{b} \mathrm{P} \leq 0.05$ control group with 5-fluorouracil compared to the other groups (one-way ANOVA).

Table 2. Number of erythrocytes, hemoglobin concentration, hematocrit, number of reticulocytes and total number of leukocytes, neutrophils, lymphocytes, monocytes, and total and differential counts of bone marrow cells from the control and malnourished animals treated or not with 5 -fluorouracil.

\begin{tabular}{|c|c|c|c|c|}
\hline \multirow[t]{2}{*}{ Parameters } & \multicolumn{2}{|c|}{ Control } & \multicolumn{2}{|c|}{ Malnourished } \\
\hline & $\begin{array}{l}\text { Without 5-fluorouracil } \\
\qquad(\mathrm{N}=9)\end{array}$ & $\begin{array}{c}10 \text { days after } \\
\text { 5-fluorouracil }(\mathrm{N}=7)\end{array}$ & $\begin{array}{l}\text { Without 5-fluorouracil } \\
\qquad(\mathrm{N}=9)\end{array}$ & $\begin{array}{c}10 \text { days after } \\
5 \text {-fluorouracil }(\mathrm{N}=7)\end{array}$ \\
\hline Erythrocytes $\left(\times 10^{6} / \mathrm{mm}^{3}\right)$ & $9.04 \pm 0.88$ & $9.53 \pm 0.17$ & $7.15 \pm 0.93^{a, b}$ & $7.16 \pm 0.80^{\mathrm{a}, \mathrm{b}}$ \\
\hline Hemoglobin $(\mathrm{g} / \mathrm{dL})$ & $13.46 \pm 2.44$ & $12.83 \pm 0.32$ & $10.14 \pm 1.03^{a, b}$ & $9.75 \pm 0.65^{a, b}$ \\
\hline Reticulocytes (\%) & $4.53 \pm 0.79$ & $11.30 \pm 3.88^{a}$ & $2.49 \pm 0.65^{a, b}$ & $1.35 \pm 1.08^{\mathrm{a}, \mathrm{b}}$ \\
\hline Peripheral leukocytes $\left(/ \mathrm{mm}^{3}\right)$ & $2833 \pm 211$ & $3050 \pm 183$ & $1193 \pm 111^{\mathrm{a}, \mathrm{b}}$ & $1026 \pm 54.1^{\mathrm{a}, \mathrm{b}}$ \\
\hline Peripheral neutrophils $\left(/ \mathrm{mm}^{3}\right)$ & $1395 \pm 181$ & $1992 \pm 97.9^{a}$ & $339 \pm 15.6^{a, b}$ & $402 \pm 2.25^{a, b}$ \\
\hline Peripheral lymphocytes $\left(/ \mathrm{mm}^{3}\right)$ & $1468 \pm 183$ & $1058 \pm 59.9$ & $703 \pm 24.5^{a, b}$ & $624 \pm 3.26^{a, b}$ \\
\hline Peripheral monocytes $\left(/ \mathrm{mm}^{3}\right)$ & $3.14 \pm 2.33$ & $0.06 \pm 0.01^{a}$ & $7.80 \pm 1.26^{a, b}$ & $0.06 \pm 0.01^{\mathrm{a}, \mathrm{c}}$ \\
\hline Total bone marrow cells $\left(\times 10^{5} / \mathrm{mm}^{3}\right)$ & $151.7 \pm 33.1$ & $94.3 \pm 37.1^{\mathrm{a}}$ & $84.4 \pm 25.3^{a}$ & $36.9 \pm 6.6^{a, b, c}$ \\
\hline Bone marrow blast cells $\left(\times 10^{5} / \mathrm{mm}^{3}\right)$ & $1.69 \pm 0.65$ & $0.72 \pm 0.43^{a}$ & $0.76 \pm 0.32^{a}$ & $0.41 \pm 0.31^{a}$ \\
\hline $\begin{array}{l}\text { Bone marrow promyelocytic, myelocytic } \\
\text { and metamyelocytic cells }\left(\times 10^{5} / \mathrm{mm}^{3}\right)\end{array}$ & $11.16 \pm 2.49$ & $3.51 \pm 0.98^{a}$ & $3.63 \pm 2.78^{a}$ & $1.81 \pm 0.42^{\mathrm{a}, \mathrm{b}, \mathrm{c}}$ \\
\hline Bone marrow band cells $\left(\times 10^{5} / \mathrm{mm}^{3}\right)$ & $19.81 \pm 2.42$ & $8.21 \pm 1.31^{\mathrm{a}}$ & $6.92 \pm 1.21^{a}$ & $4.67 \pm 1.56^{a, b}$ \\
\hline Bone marrow segmented $\left(\times 10^{5} / \mathrm{mm}^{3}\right)$ & $50.01 \pm 4.36$ & $30.01 \pm 2.36^{a}$ & $17.69 \pm 2.18^{a, b}$ & $11.99 \pm 2.76^{\mathrm{a}, \mathrm{b}, \mathrm{c}}$ \\
\hline Bone marrow eosinophils $\left(\times 10^{5} / \mathrm{mm}^{3}\right)$ & $3.37 \pm 2.96$ & $1.01 \pm 0.89$ & $1.01 \pm 1.90$ & $0.54 \pm 0.24^{a}$ \\
\hline Bone marrow lymphocytes $\left(\times 10^{5} / \mathrm{mm}^{3}\right)$ & $38.21 \pm 2.04$ & $18.06 \pm 2.60^{a}$ & $26.48 \pm 2.24^{a}$ & $17.84 \pm 2.15^{a, c}$ \\
\hline Bone marrow macrophages $\left(\times 10^{5} / \mathrm{mm}^{3}\right)$ & $2.52 \pm 1.96$ & $0.58 \pm 0.60^{\mathrm{a}}$ & $0.70 \pm 0.70^{\mathrm{a}}$ & $0.31 \pm 0.48^{a}$ \\
\hline Bone marrow total erytroblasts $\left(\times 10^{5} / \mathrm{mm}^{3}\right)$ & 3) $43.64 \pm 3.36$ & $32.24 \pm 2.43^{a}$ & $26.59 \pm 2.81^{a, b}$ & $29.41 \pm 2.68^{a, b}$ \\
\hline
\end{tabular}

Data are reported as means \pm SEM. aP $\leq 0.05$ control group without 5 -fluorouracil compared to the other groups; ${ }^{b} P \leq 0.05$ control group with 5 -fluorouracil compared to the other groups. ${ }^{\mathrm{CP}} \leq 0.05$ malnourished group without 5 -fluorouracil compared to the malnourished group treated with 5-fluorouracil (one-way ANOVA). 

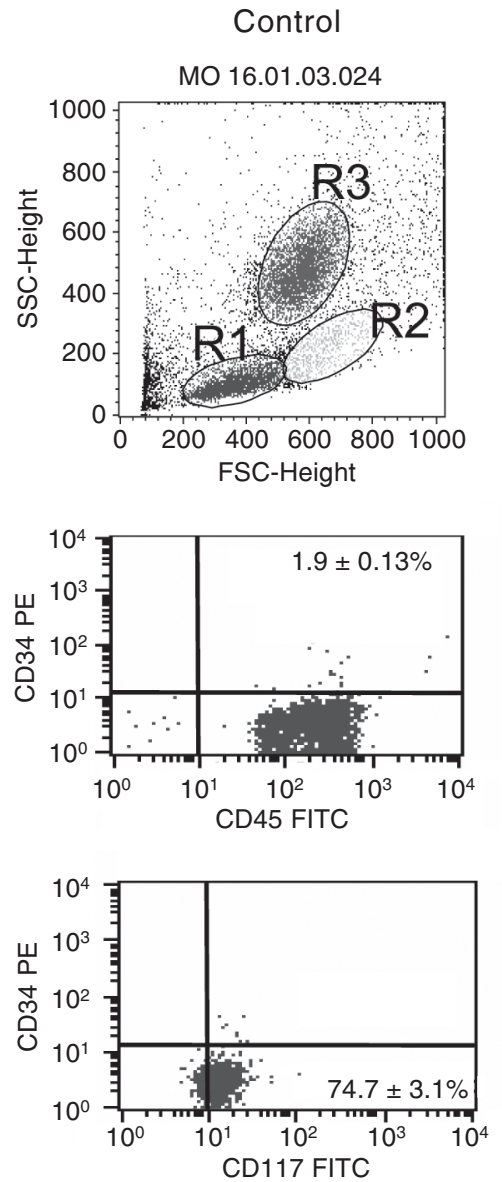

similar, with fewer cells expressing CD45 compared with control animals that received 5-fluorouracil (data not shown).

\section{Cell cycle}

The cell cycle in bone marrow cells was evaluated using the propidium iodide technique and flow cytometry (Table 3 ). Control animals showed a lower percentage of cells in the G0/G1 phases than did malnourished animals. The control animals presented a higher percentage of cells in the S/G2/M phases compared to malnourished animals. Control animals that received 5-fluorouracil also presented fewer cells in the G0/G1 phase compared to their respective malnourished groups.

Analysis of the cell cycle using the acridine orange technique (Table 4) showed that animals from the control group had fewer cells in the G0 phase compared to malnourished animals. Control animals, which received 5-
Figure 1. A, Flow cytometry analyses of bone marrow from control and malnourished mice shows the selections of gates R1, R2 and R3 of the cell populations that were not marked with fluorochromes (SSC on the $y$-axis vs FSC on the x-axis). The immunophenotypic bone marrow analysis was carried out in gate R1 and shows CD45 vs CD34 cells and CD117 vs $\mathrm{CD} 34$ cells from the bone marrow of control $(\mathrm{N}=6)$ and malnourished $(\mathrm{N}=6)$ animals. The graphs are representative of the five independent experiments, each showing similar results. A total of $10^{4}$ cells were analyzed in a flow cytometer using a 488-nm argon laser, FACSCalibur (Becton Dickinson). SSC = side scatter; FSC = forward scatter; $P E=$ phycoerythrin; FITC = fluorescein isothiocyanate. ${ }^{*} \mathrm{P} \leq$ 0.05 compared to control (one-way ANOVA).

G0/G1 cell cycle phases and S/G2/M cell cycle phases of bone marrow cells from the control and malnourished animals treated or not with 5-fluorouracil using the propidium iodide technique.

\begin{tabular}{|c|c|c|c|c|}
\hline \multirow[t]{2}{*}{ Parameters } & \multicolumn{2}{|c|}{ Control } & \multicolumn{2}{|c|}{ Malnourished } \\
\hline & $\begin{array}{l}\text { Without } \\
\text { 5-fluorouracil } \\
(\mathrm{N}=9)\end{array}$ & $\begin{array}{l}10 \text { days after } \\
5 \text {-fluorouracil } \\
\quad(\mathrm{N}=7)\end{array}$ & $\begin{array}{c}\text { Without } \\
\text { 5-fluorouracil } \\
\quad(\mathrm{N}=9)\end{array}$ & $\begin{array}{l}10 \text { days after } \\
5 \text {-fluorouracil } \\
\quad(\mathrm{N}=7)\end{array}$ \\
\hline G0/G1 & $80.17 \pm 2.68$ & $78.84 \pm 2.32$ & $87.12 \pm 2.73^{a, b}$ & $84.99 \pm 0.44^{a, b}$ \\
\hline S/G2/M & $19.78 \pm 2.64$ & $19.77 \pm 8.36$ & $13.32 \pm 2.32^{a}$ & $19.61 \pm 4.54$ \\
\hline
\end{tabular}

Data are reported as means \pm SEM. aP $\leq 0.05$ control group without 5 -fluorouracil compared to the other groups; ${ }^{\mathrm{bP}} \leq 0.05$ control group with 5 -fluorouracil compared to the other groups (one-way ANOVA).

fluorouracil, also presented fewer G0 cells than the respective malnourished group.

Both the propidium iodide technique and the acridine orange test showed that malnourished animals had a higher percentage of cells in the G0 phase of the cell cycle. 
Table 4. Total G0, G1, S, and G2/M cell cycle phases of bone marrow cells from control and malnourished animals treated or not with 5-fluorouracil using the acridine orange technique.

\begin{tabular}{|c|c|c|c|c|}
\hline \multirow[t]{2}{*}{ Parameters } & \multicolumn{2}{|c|}{ Control } & \multicolumn{2}{|c|}{ Malnourished } \\
\hline & $\begin{array}{l}\text { Without } \\
\text { 5-fluorouracil } \\
(\mathrm{N}=9)\end{array}$ & $\begin{array}{l}10 \text { days after } \\
5 \text {-fluorouracil } \\
\quad(\mathrm{N}=7)\end{array}$ & $\begin{array}{l}\text { Without } \\
\text { 5-fluorouracil } \\
(\mathrm{N}=9)\end{array}$ & $\begin{array}{l}10 \text { days after } \\
5 \text {-fluorouracil } \\
\quad(\mathrm{N}=7)\end{array}$ \\
\hline G0 & $28.13 \pm 4.18$ & $54.91 \pm 11.75^{a}$ & $54.17 \pm 15.76^{a}$ & $60.17 \pm 3.85^{a, b, c}$ \\
\hline G1 & $53.96 \pm 3.83$ & $38.95 \pm 12.28^{a}$ & $31.32 \pm 14.90^{\mathrm{a}}$ & $20.76 \pm 7.10^{a, b, c}$ \\
\hline $\mathrm{S}$ & $9.51 \pm 3.09$ & $8.79 \pm 2.50$ & $6.20 \pm 2.91^{a}$ & $8.24 \pm 2.79^{c}$ \\
\hline G2/M & $8.72 \pm 4.50$ & $10.97 \pm 6.63$ & $5.91 \pm 0.94^{a}$ & $10.87 \pm 2.11^{c}$ \\
\hline
\end{tabular}

Data are reported as means \pm SEM. aP $\leq 0.05$ control group without 5 -fluorouracil compared to the other groups; ${ }^{\mathrm{b}} \mathrm{P} \leq 0.05$ control group with 5-fluorouracil compared to the other groups. ${ }^{\mathrm{CP}} \leq 0.05$ malnourished group without 5 -fluorouracil compared to the malnourished group treated with 5-fluorouracil (one-way ANOVA).

\section{Discussion}

This study confirms that protein malnutrition produces alterations in bone marrow that lead to cellular depletion. This, in turn, results in anemia with significant reticulocyte reduction and leukopenia. The immunophenotypic analysis demonstrated the depletion of progenitor populations and the cell cycle analysis showed that more cells were in the G0 phase in the malnourished animals.

Since the minimum daily amounts of nutrients other than protein were ingested by the animals of the malnourished group, we may conclude that the changes observed in our experimental model are mainly the result of the decrease in protein and energy intake.

According to Suda et al. (23), the weaker leukocyte response to bacterial infections in protein-energy malnutrition is due to a reduction in the reserve compartment of the bone marrow. Deo (24) observed that monkeys submitted to low-protein diets presented alterations in the intestinal mucosa secondary to a decrease in cell proliferation. Fried et al. (9) reported that mice submitted to protein-free diets, after receiving sublethal doses of radiation, presented a reduction in the number of granulocytic colony forming units. Ortiz and Betancourt (25) demonstrated a relationship between protein deficiency and the proliferation of hemopoietic cells. The bone marrow hypocellularity found in this study was also reported by Fló et al. (26) and Olmos et al. (16).

Our study showed that malnourished animals present a higher percentage of cells in the G0 phase of development. This is combined with a smaller number of cells exhibiting $\mathrm{CD}_{3}{ }^{+}, \mathrm{CD}_{4} 5^{+}$and $\mathrm{CD} 117^{+}$. We conclude that this is one of the factors responsible for the marrow hypo- plasia observed here, partially explaining our results $(27,28)$.

The reason for administering 5-fluorouracil was to halt the development of most bone marrow cells at or even before the G0 phase of the cell cycle. Our goal was to subsequently evaluate the ability of the cells to resume development. Ten or 15 days after 5-fluorouracil administration, our results demonstrated that cells from the malnourished animals were not as readily able to resume development as those from the control animals (data not shown).

The anemia, leukopenia and marrow atrophy found in the mice submitted to protein-energy malnutrition suggest a decrease in the proliferative capacity of progenitor cells. The decrease in the marrow compartment was a result of more cells in the G0 phase of the cell cycle and was not a result of an increase of the efflux of bone marrow cells to peripheral blood and/or an increase in apoptosis. Our group (27) used clonogenic assays to demonstrate that cells from the bone marrow of malnourished animals showed less ability to differentiate.

One of the prerequisites for hemopoiesis is the establishment of stem cells within the microenvironment in order to enable possible cell-cell and cell-extracellular matrix (ECM) interactions (29). Hemopoiesis occurs within the context of the unique marrow microenvironment, where stromal cells and components of the ECM modulate the growth and differentiation of hemopoietic progenitors (30). Few studies exist that explore the relationship between malnutrition and the ECM. Lyra et al. (31) observed an increase in ECM density within the thymus in malnourished children, which was considered to be responsible for the depletion of thymocytes. Reif et al. (32) found a decrease in ECM components within the liver.

The mechanisms that lead to these changes have not been elucidated. Considering that ECM molecules are involved in the adhesion, regulation, proliferation, differentiation, and migration of hematopoietic cells, these changes may be highly significant for the physiology of the tissue.

In ex vivo cultures, the population of progenitor cells in the $\mathrm{S} / \mathrm{G} 2 / \mathrm{M}$ phases is mostly related to fibronectin. In contrast, cells in G0 are more frequently not adhered. This suggests that cell cycle transition is associated with adhesion to fibronectin $(33,34)$. However, the activation of the cell cycle does not cause adhesion of the cell to fibronectin since cells in various stages of the cell cycle have been found in non-adherent fractions. Giet et al. (33) also ob- 
served that cell adhesion consistent with the phase of development is mediated by VLA-5. Cytokine-related stimulation allows the overexpression of this receptor. The abnormalities found in ECM components could alter the co-localization of the diverse growth factors and cytokines, which are required to modulate the growth and differentiation process of hematopoietic cells $(12,28,35)$. This in turn may alter the cell-cell and cell-ECM interactions, thereby modifying the signaling pathways and leading to bone marrow hypoplasia with a depletion of progenitor hematopoietic populations and peripheral pancytopenia. These data may partially justify the increase in susceptibility to infection observed in malnourished individuals.

\section{Acknowledgments}

The authors thank Prof. Dr. Roger Chammas for technical assistance.

\section{References}

1. de Onis M, Monteiro C, Akre J, Glugston G. The worldwide magnitude of protein-energy malnutrition: an overview from the WHO Global Database on Child Growth. Bull World Health Organ 1993; 71: 703-712.

2. Latham MC. Protein-energy malnutrition - its epidemiology and control. J Environ Pathol Toxicol Oncol 1990; 10: 168180.

3. Brundtland GH. Nutrition and infection: malnutrition and mortality in public health. Nutr Rev 2000; 58: S1-S4.

4. Keusch GT. The history of nutrition: malnutrition, infection and immunity. J Nutr 2003; 133: 336S-340S.

5. Borelli P, Mariano M, Borojevic R. Protein malnutrition: effect on myeloid cell production and mobilization into inflammatory reactions in mice. Nutr Res 1995; 15: 1477-1485.

6. De la Fuente M, Munoz ML. Impairment of phagocytic process in macrophages from young and old mice by protein malnutrition. Ann Nutr Metab 1992; 36: 41-47.

7. Fock RA, Silva OPPS, Borelli P. Desnutrição protéica modifica a síntese de óxido nítrico em macrófagos. Rev Bras Ciên Farm 2003; 39 (Suppl 3): 115-118.

8. Fock RA, Vinolo MA, de Moura Sa Rocha V, de Sa Rocha LC, Borelli $P$. Protein-energy malnutrition decreases the expression of TLR-4/MD-2 and CD14 receptors in peritoneal macrophages and reduces the synthesis of TNF-alpha in response to lipopolysaccharide (LPS) in mice. Cytokine 2007; 40: 105-114.

9. Fried W, Barone SJ, Anagnostou A. Effect of protein deprivation on hematopoietic stem cells and on peripheral blood counts. J Lab Clin Med 1978; 92: 303-310.

10. Dunki Jacobs PB, Ruevekamp M, Hart GA, de Graaf PW. Dietary influences on cell proliferation in bone marrow. Eur $J$ Cancer Clin Oncol 1989; 25: 953-957.

11. Vinolo MA, Crisma AR, Nakajima $K$, Rogero MM, Fock RA, Borelli P. Malnourished mice display an impaired hematologic response to granulocyte colony-stimulating factor administration. Nutr Res 2008; 28: 791-797.

12. Xavier JG, Favero ME, Vinolo MA, Rogero MM, Dagli ML, Arana-Chavez VE, et al. Protein-energy malnutrition alters histological and ultrastructural characteristics of the bone marrow and decrease haematopoiesis in adult mice. Histol Histopathol 2007; 22: 651-660.

13. King LE, Fraker PJ. Variations in the cell cycle status of lymphopoietic and myelopoietic cells created by zinc deficiency. J Infect Dis 2000; 182 (Suppl 1): S16-S22.
14. Vaisman N, Barak Y, Hahn T, Karov Y, Malach L, Barak V. Defective in vitro granulopoiesis in patients with anorexia nervosa. Pediatr Res 1996; 40: 108-111.

15. Cortes E, Gonzalez C, Betancourt M, Ortiz R. Assessment of DNA damage in spleen, bone marrow, and peripheral blood from malnourished rats by single cell gel electrophoresis assay. Teratog Carcinog Mutagen 2001; 21: 231-247.

16. Olmos S, Reinoso MF, Marquez MG, Roux ME. Cytogenetic studies in bone marrow cells from Wistar rats in protein malnutrition. Metabolism 2001; 50: 1025-1029.

17. Reeves PG, Nielsen FH, Fahey GC Jr. AIN-93 purified diets for laboratory rodents: final report of the American Institute of Nutrition ad hoc writing committee on the reformulation of the AIN-76A rodent diet. J Nutr 1993; 123: 1939-1951.

18. Ward PG. A micro-Kjeldahl procedure for field use. J Med Lab Technol 1963; 20: 191-195.

19. Dacie JV, Lewis SM. Practical haematology. New York: Churchill Livingstone; 1995.

20. Doumas BT, Watson WA, Biggs HG. Albumin standards and the measurement of serum albumin with bromcresol green. Clin Chim Acta 1971; 31: 87-96.

21. Gornall AG, Bardawill CJ, David MM. Determination of serum proteins by means of the biuret reaction. $\mathrm{J} \mathrm{Biol} \mathrm{Chem}$ 1949; 177: 751-766.

22. Hsieh T, Halicka D, Lu X, Kunicki J, Guo J, Darzynkiewicz $Z$, et al. Effects of resveratrol on the $G(0)-G(1)$ transition and cell cycle progression of mitogenically stimulated human lymphocytes. Biochem Biophys Res Commun 2002; 297: 1311-1317.

23. Suda AK, Mathur M, Deo K, Deo MG. Kinetics of mobilization of neutrophils and their marrow pool in protein-calorie deficiency. Blood 1976; 48: 865-875.

24. Deo MG. Cell biology of protein-calorie malnutrition. World Rev Nutr Diet 1978; 32: 49-95.

25. Ortiz R, Betancourt M. Cell proliferation in bone marrow cells of severely malnourished animals. J Nutr 1984; 114 : 472-476.

26. Fló J, Elias F, Benedetti R, Massouh E. Reversible effects on $B$ and $T$ cells of the gut-associated lymphoid tissues in rats malnourished during suckling: impaired induction of the immune response to intra-Peyer patches immunization with cholera toxin. Clin Immunol Immunopathol 1996; 80: 147154.

27. Borelli P, Blatt S, Pereira J, de Maurino BB, Tsujita M, de 
Souza AC, et al. Reduction of erythroid progenitors in protein-energy malnutrition. Br J Nutr 2007; 97: 307-314.

28. Vituri CL, Alvarez-Silva M, Trentin AG, Borelli P. Alterations in proteins of bone marrow extracellular matrix in undernourished mice. Braz J Med Biol Res 2000; 33: 889-895.

29. Tavassoli M, Minguell JJ. Homing of hemopoietic progenitor cells to the marrow. Proc Soc Exp Biol Med 1991; 196: 367373.

30. Bentley SA. Close range cell:cell interaction required for stem cell maintenance in continuous bone marrow culture. Exp Hematol 1981; 9: 308-312.

31. Lyra JS, Madi K, Maeda CT, Savino W. Thymic extracellular matrix in human malnutrition. J Pathol 1993; 171: 231-236.

32. Reif S, Lu RB, Tano M, Terranova V, Young C, Fisher J, et al. Perinatal food restriction in rats reduces the content but not concentration of liver extracellular matrix proteins. $J$ Nutr 1993; 123: 811-816.

33. Giet $O$, Huygen $S$, Beguin $Y$, Gothot A. Cell cycle activation of hematopoietic progenitor cells increases very late antigen-5-mediated adhesion to fibronectin. Exp Hematol 2001; 29: $515-524$

34. Giet O, Van Bockstaele DR, Di Stefano I, Huygen S, Greimers R, Beguin Y, et al. Increased binding and defective migration across fibronectin of cycling hematopoietic progenitor cells. Blood 2002; 99: 2023-2031.

35. Klein G. The extracellular matrix of the hematopoietic microenvironment. Experientia 1995; 29: 914-926. 